\title{
Observations on obese patients eating isocaloric reducing diets with varying proportions of carbohydrate
}

\author{
BY CATHRYN E. A. HOOD, J. M. GOODHART, \\ R. F. FLETCHER, JOSEPHINE GLOSTER, P. V. BERTRAND \\ AND A. C. CROOKE \\ Metabolic Research Unit, East Birmingham Hospital, and the Departments of \\ Medicine and Clinical Endocrinology, University of Birmingham
}

(Received 28 February 1969-Accepted 30 fune 1969)

\begin{abstract}
1. Diets containing $1000 \mathrm{kcal} /$ day with varying proportions of carbohydrate (CHO) were fed to four women with simple obesity. The patients were given, in various sequences and for 8 days in each instance, diets in which $3,6,12,25$ or $50 \%$ of the calories were supplied by sucrose.

2. No significant difference in the rate of weight loss was found when the diets of graded CHO content were fed and mean weight loss was $\mathrm{I} \cdot 2 \mathrm{~kg} /$ week.

3. The high-CHO diets were antiketogenic; there was no daily relationship between urinary ketones and sodium. The 25 and $50 \%$ CHO diets had a nitrogen-sparing effect.

4. A $1000 \mathrm{kcal} / \mathrm{day}$ diet with about a third of the calories derived from CHO leads to a useful rate of weight loss and minimum changes in body chemistry. This finding may have implications in the long-term treatment of obesity.
\end{abstract}

Over long periods of time the composition of a low-calorie diet probably has no effect on the rate of weight loss (Werner, 1955; Oleson \& Quaade, 1960; Pilkington, Gainsborough, Rosenoer \& Carey, 1960; Fletcher, McCririck \& Crooke, 1961; Kinsell, Gunning, Michaels, Richardson, Cox \& Lemon, r964). In the short-term, however, the composition of the diet is relevant (Lyon \& Dunlop, 1932; Anderson, r944) and carbohydrate (CHO) is the most important factor. A low-calorie diet of high CHO content causes less weight loss or even weight gain compared with a low-calorie diet composed of protein and fat (Kekwick \& Pawan, 1956). Investigations using diets with different $\mathrm{CHO}$ contents (Russell, 1962) or CHO loads after fasting (Bloom, I962 $a$; Jones, Albrink, Davidson \& Flink, 1966) have shown that the absolute or relative increase in weight is due to the retention of sodium and water although the cause of this is unknown.

Low-calorie diets of low $\mathrm{CHO}$ content are recommended for the treatment of obesity (Yudkin \& Carey, 1960) but some effects of these diets seem undesirable. Considerable nitrogen loss may occur (Jones et al. 1966) reflecting wasting of lean tissue. Ketosis may appear (Bloom, $1962 b$ ) and although it has been claimed that obese persons are partially resistant to it (Kekwick, Pawan \& Chalmers, 1959) this is disputed (Carey, Pilkington \& Titterington, 1962).

We have attempted to determine whether there is an optimum level of $\mathrm{CHO}$ which can be recommended by examining the changes in weight and metabolic effects induced by diets of varying $\mathrm{CHO}$ content.

An earlier experiment (unpublished) had shown that during a $1000 \mathrm{kcal} /$ day diet in 
which half of the calories were derived from $\mathrm{CHO}$, similar effects were obtained using starch, lactose or sucrose. For convenience, and because it caused slightly greater salt and water retention than the others, sucrose was used in the present study.

\section{EXPERIMENTAL}

Subjects. Four patients were studied (Table r). They were obese women who had taken reducing diets in the past, but their weights had been steady or rising during the 6 months before admission. Except for the obesity, physical examination was normal as were all investigations including tests of adrenal and thyroid function, and routine blood and urine tests.

\section{Table r. Details of the four patients on admission}

\begin{tabular}{|c|c|c|c|c|c|}
\hline Patient no. & $\begin{array}{l}\text { Married } \\
\text { single }\end{array}$ & Age (years) & Height $(\mathrm{cm})$ & Weight (kg) & $\begin{array}{c}\% \text { above ideal } \\
\text { weight }\end{array}$ \\
\hline$I(938 I I) \dagger$ & M & 28 & I 68 & 103 & 44 \\
\hline $2(96483) \dagger$ & $\mathrm{S}$ & 17 & 164 & 83 & 42 \\
\hline $3(95620) \dagger$ & $\mathrm{S}$ & 17 & 165 & 94 & $4^{I}$ \\
\hline $4(16113)+$ & $\mathrm{M}$ & 46 & 150 & 92 & 46 \\
\hline
\end{tabular}

The patients were studied under close supervision in a metabolic ward. After admission to hospital they were given a free choice of diet for up to 4 days while preliminary investigations were carried out. The patients were up and dressed most of the day and took occasional short walks in the hospital grounds. The accommodation is not air-conditioned but maintains a fairly even temperature.

Diets. 'To reduce variations in the diet, batches of meat and frozen vegetables were prepared in advance. The patients took three meals a day at $07.45,12.00$ and $17.30 \mathrm{~h}$. The diets were designed with the use of food tables (McCance \& Widdowson, 1960) to yield rooo kcal/day, of which $3-50 \%$ was derived from CHO. Except for the $3 \%$ $\mathrm{CHO}$ diet, which had the irreducible minimum $\mathrm{CHO}$ content, the $\mathrm{CHO}$ proportion was made up with appropriate amounts of Analar sucrose $\left(3.9^{6} \mathrm{kcal} / \mathrm{g}\right)$ which was taken in flavoured drinks. The protein and fat contents of the diets were adjusted accordingly.

Water intake was measured as fluid drunk plus the water contents of the diets as determined by desiccation. The sodium content of the diets was always less than Io m-equiv./day but was made up to $78 \mathrm{~m}$-equiv./day with a sodium chloride supplement given orally in capsules.

Body-weight and collection of excreta. Each morning at $09.00 \mathrm{~h}$ the patients, wearing light clothing of the same type, were weighed on an Avery chair scale. Usually the patients had taken breakfast by then, but on the Ist morning of each new dietary regimen they had been fasted for $12 \mathrm{~h}$. All urine and faeces were measured at $09.00 \mathrm{~h}$ each day, having been collected into containers maintained at $4^{\circ}$.

Analyses. Complete duplicate diets were prepared once for each patient. Nitrogen 
content was estimated on samples of food, faecal homogenates and urine by the microKjeldahl method; the sodium content was determined by flame photometry. The calorie content of urine and of food and faecal homogenates was determined by bomb calorimetry (Miller \& Payne, 1959). The specimens of urine and faeces were pooled over 4 days. On the Ist day of each dietary regimen venous blood was drawn at $09.00 \mathrm{~h}$ with the patient at rest and having fasted for $12 \mathrm{~h}$. Free fatty acids (FFA) in the serum were estimated according to Dole \& Meinertz (1960). Total ketones in serum and urine were estimated according to Procos (I96I) with one exception. The samples with sulphuric acid and dichromate were (instead of refluxing) sealed in thick-walled glass tubes $\mathrm{I} 5 \mathrm{~cm}$ long and kept at $120^{\circ}$ for $0.5 \mathrm{~h}$ in a sand tray.

Water output was calculated as urine volume plus $75 \%$ of the volume of the faeces.

Procedure. The patients were given diets in which the percentages of calories derived from $\mathrm{CHO}$ were $3,6,12,25$ and $5^{\circ}$. A logarithmic scale was chosen because it was expected that some of the effects of varying $\mathrm{CHO}$ percentage would be exponential.

Each diet was given for 8 days and all the patients had each of the diets at least once. Patient no. 4 was studied twice. The total number of periods on each diet is shown in Table 3. The order in which the diets were given was different for each patient; a Latin square design was intended but an error resulted in the final layout being slightly asymmetrical.

Statistical methods. All results were expressed as means per day over 4 -day periods and were analysed by standard methods of least squares assuming additive effects of patients, diets and order in time (Kempthorne, 1952). Significant effects of the diets were investigated by fitting regressions of effects on the logarithm of percentage CHO. The significance of the following three relationships was investigated:

(I) Linear regression of the mean effect over each 8-day period on diets.

(2) The mean difference between the first and second 4-day periods.

(3) Linear regression of the difference between the first and second 4 -day periods on diets.

Calculations were carried out on the University of Birmingham KDF 9 computer with a programme written by one of us (P.V.B.).

\section{RESULTS}

The diets analysed by calorimetry all contained between 1037 and $1132 \mathrm{kcal} /$ day. The calorie contents of some specimens of urine and faeces were estimated and were together about $150 \mathrm{kcal} /$ day. Fluid intake was always between 1950 and $2050 \mathrm{ml} /$ day.

Weight loss. The mean weight loss was $0.17 \mathrm{~kg} / \mathrm{day}$ (standard error of the mean \pm 0.02 , $P<0.001)$, but the variation between the patients was not significant and there was no trend with time (Table 2). Although the weight loss was lowest (about $0 \cdot 15 \mathrm{~kg} /$ day) on the high-CHO diets there was no significant difference between the diets.

Nitrogen balance. During the first 4-day periods there was no consistent effect from the different diets. In the second 4 -day periods the nitrogen balances were progressively less negative with the diets of higher $\mathrm{CHO}$ content and the 25 and $50 \%$ CHO diets had a similar but more marked effect (Table 3 ). 
Urinary sodium. The variation between the diet effects was not significant but when the means for each 8-day period were considered a linear trend was detected $(P<$ 0.05 ) of lower urinary sodium on high-CHO diets (Table 2). At 3 and $50 \%$ CHO the mean values for urinary sodium were 60.8 and $47.5 \mathrm{~m}$-equiv./day respectively. The patients had significantly different $(P<0.001)$ mean levels. Urinary sodium was examined in relation to the urinary ketones. When the means for each diet were compared there was a positive correlation $(r=+0.94, P<0.02)$, but when daily values and individual patients were examined no correlation could be found.

Table 2. Mean values with their standard errors for weight loss, water output, urinary sodium, urinary ketones, serum ketones and serum free fatty acids in the four women

\begin{tabular}{|c|c|c|c|c|c|c|c|}
\hline $\begin{array}{c}\text { Dietary calories } \\
\text { derived from } \\
\text { carbohydrate } \\
(\%)\end{array}$ & $\begin{array}{l}\text { 4-day } \\
\text { period } \\
\text { no. }\end{array}$ & $\begin{array}{l}\text { Wt loss } \\
\text { (kg/day) }\end{array}$ & $\begin{array}{l}\text { Water } \\
\text { output } \\
\text { (ml/day) }\end{array}$ & $\begin{array}{c}\text { Urinary } \\
\text { sodium } \\
\text { excretion } \\
\text { (m-equiv./ } \\
\text { day) }\end{array}$ & $\begin{array}{l}\text { Urinary } \\
\text { ketone } \\
\text { excretion } \\
\text { (mg/day) }\end{array}$ & $\begin{array}{l}\text { Serum } \\
\text { ketones* } \\
(\mathrm{mg} / \\
\text { I00 } \mathrm{ml})\end{array}$ & $\begin{array}{l}\text { Serum free } \\
\text { fatty acids* } \\
(\mu \text {-equiv./1.) }\end{array}$ \\
\hline 3 & $\begin{array}{l}1 \\
2\end{array}$ & $\begin{array}{l}0.192 \pm 0.058 \\
0.242 \pm 0.054\end{array}$ & $\begin{array}{l}1402 \pm 38 \\
1360 \pm 67\end{array}$ & $\begin{array}{l}63 \cdot 4 \pm 4 \cdot 0 \\
61 \cdot 6 \pm 6 \cdot 3\end{array}$ & $\begin{array}{l}\text { rI } 73 \pm 121 \\
1607 \pm 64\end{array}$ & $\frac{-}{27.5 \pm 3.0}$ & $\overline{1427 \pm 130}^{-}$ \\
\hline 6 & $\begin{array}{l}1 \\
2\end{array}$ & $\begin{array}{l}0.096 \pm 0.041 \\
0.246 \pm 0.077\end{array}$ & $\begin{array}{l}1294 \pm 38 \\
1257 \pm 57\end{array}$ & $\begin{array}{l}60.0 \pm 5.7 \\
60.5 \pm 4.2\end{array}$ & $\begin{array}{l}994 \pm 119 \\
\text { I } 140 \pm 78\end{array}$ & $26 \cdot 0 \pm 3 \cdot 6$ & $1326 \pm$ I 88 \\
\hline I 2 & $\begin{array}{l}\text { I } \\
2\end{array}$ & $\begin{array}{l}0.157 \pm 0.043 \\
0.212 \pm 0.055\end{array}$ & $\begin{array}{l}1361 \pm 51 \\
1323 \pm 43\end{array}$ & $\begin{array}{l}56 \cdot 2 \pm 4 \cdot 6 \\
54 \cdot 8 \pm 5 \cdot 4\end{array}$ & $\begin{array}{l}549 \pm 105 \\
674 \pm 112\end{array}$ & $17 \cdot \overline{8 \pm} 4 \cdot 1$ & ${ }_{1321 \pm 290}$ \\
\hline 25 & $\begin{array}{l}1 \\
2\end{array}$ & $\begin{array}{l}0.090 \pm 0.055 \\
0.210 \pm 0.040\end{array}$ & $\begin{array}{l}1213 \pm 61 \\
1352 \pm 38\end{array}$ & $\begin{array}{l}47 \cdot 5 \pm 6 \cdot 5 \\
56 \cdot 9 \pm 5 \cdot 0\end{array}$ & $\begin{array}{l}559 \pm 133 \\
428 \pm \text { I } 5\end{array}$ & $\frac{-}{3 \cdot 7 \pm 6 \cdot 2}$ & $1222 \pm 268$ \\
\hline 50 & I & $\begin{array}{l}0.158 \pm 0.092 \\
0.150 \pm 0.065\end{array}$ & $\begin{array}{l}1243 \pm 50 \\
1227 \pm 46\end{array}$ & $\begin{array}{l}44 \cdot 9 \pm 5 \cdot 4 \\
42 \cdot 7 \pm 4 \cdot 9\end{array}$ & $\begin{array}{r}224 \pm 51 \\
82 \pm 17\end{array}$ & $7 \cdot 3 \pm 2 \cdot 3$ & $\operatorname{III} 5 \pm 70$ \\
\hline
\end{tabular}

Table 3. Mean values with their standard errors for the nitrogen balances of the four women

\begin{tabular}{|c|c|c|c|c|}
\hline \multirow{2}{*}{$\begin{array}{l}\text { Dietary calories } \\
\text { derived from } \\
\text { carbohydrate }(\%)\end{array}$} & \multirow{2}{*}{$\begin{array}{l}\text { No. of } \\
\text { test periods }\end{array}$} & \multirow{2}{*}{$\begin{array}{c}\text { Nitrogen intake } \\
(\mathrm{g} / \text { day })\end{array}$} & \multicolumn{2}{|c|}{ Nitrogen balance (g/day) } \\
\hline & & & Ist 4 days & and 4 days \\
\hline 3 & 6 & 9.9 & $-3 \cdot 3 \pm 0.43$ & $-4.2 \pm 0.63$ \\
\hline 6 & 6 & $8 \cdot 9$ & $-3.4 \pm 0.65$ & $-3.4 \pm 0.37$ \\
\hline 12 & 5 & $7 \cdot I$ & $-2.9 \pm 0.65$ & $-3.2 \pm 0.47$ \\
\hline 25 & 5 & $7 \cdot 5$ & $+0.13 \pm 1.06$ & $-1.6 \pm 0.48 *$ \\
\hline 50 & 6 & $5 \cdot 5$ & $-4 \cdot 0 \pm 1 \cdot 13$ & $-1.25 \pm 0.3^{8 *}$ \\
\hline
\end{tabular}

Urinary ketones. There was no significant trend with time but there was a strong linear relation $(P<0.00 \mathrm{I})$ in that diets of higher $\mathrm{CHO}$ content were associated with lower levels of urinary ketones; at $3 \%$ and $50 \%$ CHO the mean values for urinary ketones were 1390 and $153 \mathrm{mg} /$ day respectively (Table 2). Comparing the first and second 4 -day periods, there was a sequential effect $(P<0.01)$; on the $3 \% \mathrm{CHO}$ diet the second 4-day period showed a mean increase in urinary ketones of $434 \mathrm{mg} /$ day over the first 4-day period, whereas with the $50 \%$ CHO diet a decrease of 
$142 \mathrm{mg} /$ day was noted. Patients had significantly different $(P<0.001)$ mean levels.

Serum ketones. There was a significant linear relationship $(P<0.00 \mathrm{r})$ with the levels falling from $27.5 \mathrm{mg} / \mathrm{roO} \mathrm{ml}$ on the $3 \%$ CHO diet to $7.3 \mathrm{mg} / \mathrm{I} 00 \mathrm{ml}$ on the $50 \%$ CHO diet (Table 2).

Serum FFA. The results were variable (Table 2). All the levels tended to be high, with means of $\mathrm{I}_{42} 7$ and II $5 \mu$-equiv./1., for the 3 and $50 \%$ CHO diets respectively, but the trend was not significant.

The individual values for serum ketones and FFA were correlated positively $(r=+0.36, P<0.05)$.

\section{DISCUSSION}

There was a satisfactory mean weight loss of $\mathrm{I} \cdot 2 \mathrm{~kg} /$ week during the study despite the variation in $\mathrm{CHO}$ percentage. The well-known transient effect of high-CHO feeding in arresting weight loss was not marked, possibly because the experimental design whereby the diets were fed in various sequences provided few occasions when there was a sudden change from low to high proportions of CHO. There was a significant effect of the high-CHO diets in reducing the urinary sodium but, although weight loss was lowest also during the high-CHO diets, the effect was not statistically significant. This lack of relationship between sodium output and weight loss is unexplained; the values for water output were unhelpful.

The serum and urinary ketones changed together. A considerable degree of ketosis developed with the low-CHO diets and the levels were similar to those reported by others (Jones et al. 1966) in obese patients. It is clear that $\mathrm{CHO}$ has an antiketogenic effect while calories per se do not (Jones et al. I g66; Freund, 1965). There were no symptoms which could be related to the ketosis in the patients reported here. However, another patient who started to take similar diets became more ketosed and because of associated symptoms could not continue. It has been suggested that ketosis reduces hunger (Bolinger, Lukert, Brown, Guevara \& Steinberg, 1966) but our patients did not report any change.

Apart from the general conclusion that high-CHO diets were associated with sodium retention and lack of ketosis, there was no close relationship between urinary ketones and sodium. No support could be found, therefore, for the hypothesis that the sodium retention which follows high-CHO feeding is due directly to a fall in ketone excretion. This point has been made by Bloom (1967) but he refers to an acute situation at the beginning of calorie restriction, which may not be a reliable guide.

The levels of serum FFA were generally high, as would be expected during calorie restriction. There was a loose but significant positive correlation between the levels of serum FFA and ketones, similar to that seen in diabetes mellitus and starvation (Hanson, Johnson \& Zaharko, 1965). However, whereas CHO feeding had a marked effect on ketosis, the changes in serum FFA were much smaller and less uniform. It is of interest in this connexion that a recent report (Foster, 1967) showed that changes in ketone production in the rat liver can be dissociated from fat metabolism.

The nitrogen balances during the first 4 -day periods were variable, owing perhaps 
to carry-over effects from the previous diets. When the diets were established, however, during the second 4 -day periods, the 25 and $50 \% \mathrm{CHO}$ diets were associated with much less negative nitrogen balances despite the lower protein content of these diets.

Thus a $1000 \mathrm{kcal} / \mathrm{day}$ diet containing a considerable proportion of $\mathrm{CHO}$ caused minimal disturbance of body chemistry and yet led to a satisfactory rate of weight loss. This finding may have implications in the construction of long-term diets for weight reduction in that a diet containing normal proportions of usual foods, but reduced in total amount, might be satisfactory. Such a diet would be cheaper and easier to prepare in the home than many reducing diets in current use.

We wish to thank the cooks of the Metabolic Unit for their help in the preparation of the diets, and Mrs J. Stevens, Mrs C. Haynes, Mrs T. Fishwick and the technicians of the Metabolic Unit laboratory for the chemical analyses. We are also grateful to the Medical Research Council who supported part of this study.

\section{REFERENCES}

Anderson, A. B. (1 944). Q. $\mathscr{f l} \mathrm{Med} . \mathbf{3 7}$ (OS), 27.

Bloom, W. L. (1962a). Archs intern. Med. 109, 26.

Bloom, W. L. (1962b). f. Lab. clin. Med. 59, 605.

Bloom, W. L. (1967). Am. F. clin. Nutr. 20, 157.

Bolinger, R. E., Lukert, B. P., Brown, R. W., Guevara, L. \& Steinberg, R. (1966). Archs intern. Med. $\mathbf{I} 8,3$.

Carey, M. E., Pilkington, T. R. E. \& Titterington, E. (I 962). Lancet ii, 1189.

Dole, V. P. \& Meinertz, H. (1960). F. biol. Chem. 235, 2595.

Fletcher, R. F., McCririck, M. Y. \& Crooke, A. C. (1961). Br. F. Nutr. 15, 53.

Foster, D. W. (1967). F. clin. Invest. 46, 1283.

Freund, G. (1965). Metabolism 14, 985 .

Hanson, P. G., Johnson, R. E. \& Zaharko, D. S. (I965). Metabolism 14, 1037.

Jones, J. E., Albrink, M. J., Davidson, P. C. \& Flink, E. B. (I966). Am. F. clin. Nutr. 19, 320.

Kekwick, A. \& Pawan, G. L. S. (1956). Lancet ii, I55.

Kekwick, A., Pawan, G. L. S. \& Chalmers, T. M. (I 959). Lancet ii, I 57.

Kempthorne, O. (1952). The Design and Analysis of Experiments. New York: John Wiley.

Kinsell, L. W., Gunning, B., Michaels, G. D., Richardson, J., Cox, S. E. \& Lemon, C. (1964). Metabolism 13, 195 .

Lyon, D. M. \& Dunlop, D. M. (1932). Q. Il Med. 25 (OS), 33 I.

McCance, R. A. \& Widdowson, E. M. (1960). Spec. Rep. Ser. med. Res. Coun. no. 297.

Miller, D. S. \& Payne, P. R. (1959). Br. F. Nutr. 13, 501.

Oleson, E. S. \& Quaade, F. (1960). Lancet i, 1048.

Pilkington, T. R. E., Gainsborough, H., Rosenoer, V. M. \& Carey, M. (1960). Lancet i, 856.

Procos, J. (196r). Clin. Chem. 7, 97.

Russell, G. F. M. (1962). Clin. Sci. 22, 269.

Subcommittee on Nutrition (1960). F. Am. med. Ass. 173, 1576.

Werner, S. C. (1955). New Engl. F. Med. 252, 66r.

Yudkin, J. \& Carey, M. (1960). Lancet ii, 939. 